\title{
ENERGY EFFICIENCY OF INDONESIA'S SUGAR INDUSTRY BASED ON ECONOMIC FRAMEWORK: STOCHASTIC METAFRONTIER ANALYSIS
}

\author{
Thinzar Win ${ }^{1)}$, Dyah Wulan Sari*2) and Tri Haryanto ${ }^{3)}$ \\ Universitas Airlangga ${ }^{1), 2,3)}$ \\ thinzar.win-2018@feb.unair.ac.id ${ }^{1)}$,dyah-wulansari@feb.unair.ac.id ${ }^{2}$, tri.h@feb.unair.ac.id $\left.{ }^{3}\right)$
}

\begin{abstract}
This study investigates the efficiency of energy use and technology gap in the Indonesian sugar industry and the factors influencing energy efficiency. Using the firm-level data of sugar mills in 42 regencies in Indonesia from 2010 to 2014, this study applies the meta stochastic frontier based on the input distance function. The metafrontier analysis is applied in sugar mills in the East Java province and other provinces in Indonesia. All the data used in this study are secondary data taken from the Indonesian Central Board of Statistics. The results reveal that there is a large room to save energy consumption in this industry. The mills in East Java provinces have higher energy efficiency, technology gap ratio, and metafrontier energy efficiency compared to the mills in other provinces. According to the metafrontier energy efficiency, energy inefficiencies in both groups come from operational inefficiency and technology gap. The size of the mills and age of the mills have a positive relationship with the energy efficiency of sugar mills and the size of the mills is positively related to the technology gap ratio. Meanwhile, the productivity of labor and the types of ownership do not affect the energy efficiency and technology gap.
\end{abstract}

Keywords: Energy Efficiency, Input distance function, Metafrontier, Sugar industry, the Technology gap

*Corresponding author

Email: dyah-wulansari@feb.unair.ac.id

DOI: https://doi.org/10.33369/j.akuntansi.11.1.53-66

\section{INTRODUCTION}

Sugar production is one of Indonesia's strategic industries as it is essential to meet the basic food needs of a population of nearly 273 million, supply the raw material for other industries, and create job opportunities (Susila \& Sinaga, 2005). Besides, the sugar sector in Indonesia is highly regulated with tight import controls and retail ceiling price settings. According to official data from the Bureau of Statistics in Indonesia (BPS), for the last two decades, the annual growth of sugar consumption is larger than production. From 2001 to 2018 , the average sugar consumption increased $4 \%$, with an average yearly consumption of 4.54 million tons. On the contrary, the average production increased by $1.01 \%$, with an annual average production of 2.24 million tons. In 2018, Indonesia's sugar consumption reached 6.35 million, with a per capita consumption of $25.8 \mathrm{~kg}$ per year. This amount is higher than neighboring countries such as the Philippines (19.2 kg/capita), Vietnam (15.9 kg/capita), and Cambodia (17.5 kg/capita) (ISO, 2019).

In 2018, the productivity of sugarcane in Indonesia declined by 2.56 tons/ha, with the extraction rate decreasing by $0.36 \%$ compared to 2017 . The low rate of productivity and a high level of demand likely influence the rise in sugar price. In August 2018, the domestic price of sugar was nearly three times the international market price. This high price affects households and the food and beverages (F\&B) industry. According to the report of the International Center for Applied Finance and Economics (2018), the increase in costs of inputs, higher costs of fuel, and a growing per capita gross domestic product growth have caused a rise in both price and demand for food. For instance, sugar mills' efficiency is an essential aspect as it can directly affect the selling price of sugar in the domestic market. As 
one of the main inputs of production in the sugar industry, energy efficiency is a crucial factor in controlling the rise in production cost.

Azhari (2018) reports that between 2000 to 2014, the technical efficiency in the sugar cane industry in Indonesia was $65.9 \%$ under variable return to scale and $55.7 \%$ under constant return to scale. This figure indicates that Indonesia's sugar industry has the potential to increase technical efficiency. As sugar factories are energy-intensive (Vivadinar, Purwanto, \& Saputra, 2016), one way to reduce the input cost and to improve technical efficiency is to optimize energy utilization.

In Indonesia, the production of a ton of sugar takes 5.98 barrel oil equivalent (BOE) which is high compared to the general industry standard (Specific Energy Consumption, SEC) 4.75 barrel oil equivalent (BOE) (Vivadinar et al., 2016). The increase in energy use in the sector is not only derived from the rapid structural transformation (industrialization) but also as a result of wasteful use of energy. Inefficiency in energy use will harm the industrial sector as it will be translated into a higher cost of production and lower aggregate profits. Sugiharti et al (2017) point out the fast increase in the cost of energy in manufacturing activities in Indonesia, resulting in higher production costs. In the long term, rising wastefulness of energy can cause economic inefficiency through poor allocation of resources (Ministry of Industry, 2012).

Previous studies analyzing the energy efficiency of the Indonesian manufacturing sector point out that industrial activity could further improve the use of energy inputs. Vivadinar, Purwanto, and Saputra (2012) studied the typical Specific Energy Consumption (SEC), finding that changes in energy intensity in the food processing sector are mainly explained by efficiency factors. Priambodo and Kumar (2001) analyzed the energy consumption and $\mathrm{CO}_{2}$ emission of Indonesian Small and Medium Scale Industries (SMEs), finding that the food sector employs the highest energy intensity ratio among SMEs in Indonesia. Vivadinar et al. (2016) point out that the sugar industry is intensive and inefficient in energy use for heating purposes, employing larger than usual energy to output ratios, assumed to be derived from employing old equipment. McDonald and Meylinah (2019) point out that more than 40 mills in the country are over 100 years old. Ramstetter and Narjoko (2014) studied the relationship between ownership and energy efficiency in the manufacturing sector of Indonesia, finding that no evidence of efficient use of energy derived from ownership (foreign, government, or private). According to the report of the United Nations Industrial Development Organization (2017), Indonesia Government implemented energysaving programs for GHG emissions, energy consumption, and water consumption of Pagottan Sugar Mill and Tjoekir Sugar Mill in Indonesia reducing the SEC close to a benchmark for sugar cane mills, suggesting that the sector has substantial room for improvement and that analysis of energy efficiency is crucial for the sector.

The study on energy efficiency based on the economic foundation is very rare in the sugar industry in Indonesia as it is generally analyzed within the food sector. There is still a gap in the analysis of metafrontier energy efficiency with the application of the stochastic frontier approach in sugar mills in Indonesia. To our knowledge, there is no previous study in Indonesia exploring energy efficiency and the technological gap in a large sample of mills across the country. We aim at filling this gap, by measuring the level of energy efficiency in the sugar industry in Indonesia and by exploring whether factors like age of mills, size of the mills, ownership, and labor productivity contribute to more efficient use of energy. We cover the period of 2010-2014, analyzing sugar cane mills in 42 regencies in Indonesia. The period of 2010-2014 is selected as a study period based on the Indonesian government's Road Map for a short-term period in the Sugar industry (2010-2014) and based on the updated ISIC (International Standard of Industrial Classification) code. Finally, we compare the 
performance of mills in East Java province, the largest producer of sugar in the country, versus other provinces.

\section{RESEARCH METHODS}

The meta-production function was developed by Hayami and Ruttan (1970) as the envelope of commonly conceived neoclassical production functions and it is an envelope of production points with the highest efficiency. This supposed that all mills in groups can get a range of production technologies, but each mill may select a certain technology, based on particular conditions, such as regulation, the environments, production resources, and relative input prices. These situations hamper the mills in some groups from selecting the excellent technology from the arrangement of the potential technology set. A production technology gap is a distinction between the best technology and the chosen sub-technology, i.e., the group-specific frontier.

The meta-frontier production function describes the maximum production of the maximum frontier. This function is built from each of the most efficient points of each individual in each group. Because each group has a different technology, the meta-frontier production function covers the entire frontier with different technology. This specifies that the meta-frontier production function is in a very long run period. A comparison of frontier production between groups means comparing production with different technologies so that it can be seen that there are groups whose technology is lower or higher than the others. In the long run, each group can improve its technology with its innovation or emulate other groups with higher technology. The technology shift has an impact on the shift in the group's frontier production function and eventually in the very long run period will shift the meta-frontier function upward.

Based on the neoclassical production framework, suppose a production process in which each sugar mills employs four inputs $\left(X_{i}\right)$, capital stock $(\mathrm{K})$, the labor force $(\mathrm{L})$, raw materials $(\mathrm{R})$, and Energy $(\mathrm{E})$, to produce the output, sugar, $(\mathrm{Y})$. The input distance function is defined as the biggest scalar quantity that one can proportionally decrease all inputs, energy, and other inputs, and still have the option to produce the output vector Y. Since the input distance function $\mathrm{D}_{\mathrm{I}}(\mathrm{y}, \mathrm{x})$ is described with the input sets $\mathrm{P}(\mathrm{y})$.

$\mathrm{D}_{\mathrm{I}}(\mathrm{y}, \mathrm{x})=\max \{\alpha: \mathrm{x} / \alpha \in \mathrm{P}(\mathrm{y})\}$

To consider the energy efficiency from a production efficiency' perspective, Shephard sub-vector input distance function can be used as follows:

$$
\begin{aligned}
\mathrm{D}_{\mathrm{E}} & =\left(\mathrm{X}_{\mathrm{i}}, \mathrm{Y}\right) \\
& =(\mathrm{K}, \mathrm{L}, \mathrm{R}, \mathrm{E}, \mathrm{Y}) \\
& =\sup \{\alpha:(\mathrm{K}, \mathrm{L}, \mathrm{R}, \mathrm{E} / \alpha, \mathrm{Y}) \mathrm{T}\}
\end{aligned}
$$

Equation (1) attempts to diminish the energy use as long as is viable with the resulting input-output combination in the production technology set characterized by equation (1). Thus, $\mathrm{E} / \mathrm{D}_{\mathrm{E}}=(\mathrm{K}, \mathrm{L}, \mathrm{R}, \mathrm{E}, \mathrm{Y})$ shows the hypothetical energy use if the firm is efficient in energy. At that point, the proportion of hypothetical real consumption of energy is equal to the reciprocal of the sub-vector distance function. This can be specified as the firm's energy efficiency index (EE hereafter), i.e.

$\mathrm{EE}=\frac{\mathrm{E} / \mathrm{D}_{\mathrm{E}}(\mathrm{K}, \mathrm{L}, \mathrm{R}, \mathrm{E}, \mathrm{Y})}{\mathrm{E}}$ 
ENERGY EFFICIENCY OF INDONESIA'S SUGAR INDUSTRY BASED ON ECONOMIC FRAMEWORK: STOCHASTIC METAFRONTIER ANALYSIS

Thinzar Win, Dyah Wulan Sari and Tri Haryanto

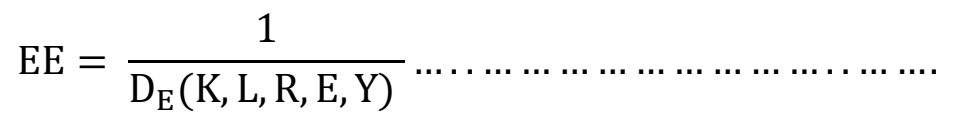

The EE is equal to one of the firms is on the best frontier. Otherwise, EE will be less than one.

Following Zhou, Ang, and Zhou (2012) and Honma and Hu (2018), the stochastic frontier distance function can be expressed in the translog production model as follows.

$$
\begin{aligned}
& \ln D_{\mathrm{E}}\left(\mathrm{K}_{\mathrm{it}}, \mathrm{L}_{\mathrm{it}}, \mathrm{R}_{\mathrm{it}}, \mathrm{E}_{\mathrm{it}}, \mathrm{Y}_{\mathrm{it}}\right)=\beta_{0}+\beta_{\mathrm{K}} \operatorname{LnK}_{\mathrm{it}}+\beta_{\mathrm{L}} \ln \mathrm{L}_{\mathrm{it}}+\beta_{R} \ln \mathrm{R}_{\mathrm{it}}+\beta_{\mathrm{E}} \ln \mathrm{E}_{\mathrm{it}}+\beta_{\mathrm{Y}} \ln \mathrm{Y}_{\mathrm{it}}+ \\
& 0.5 \beta_{\mathrm{KK}}\left(\operatorname{lnK}_{\mathrm{it}}\right)^{2}+0.5 \beta_{\mathrm{LL}}\left(\operatorname{lnL}_{\mathrm{it}}\right)^{2}+0.5 \beta_{R R}\left(\operatorname{lnR}_{\mathrm{it}}\right)^{2}+ \\
& 0.5 \beta_{\mathrm{EE}}\left(\ln \mathrm{E}_{\mathrm{it}}\right)^{2}+0.5 \beta_{\mathrm{YY}}\left(\ln \mathrm{Y}_{\mathrm{it}}\right)^{2}+\beta_{\mathrm{KL}}\left(\ln \mathrm{K}_{\mathrm{it}}\right)\left(\ln \mathrm{L}_{\mathrm{it}}\right)+ \\
& \beta_{\mathrm{KR}}\left(\ln \mathrm{K}_{\mathrm{it}}\right)\left(\ln _{\mathrm{it}}\right)+\beta_{\mathrm{KE}}\left(\ln \mathrm{K}_{\mathrm{it}}\right)\left(\ln \mathrm{E}_{\mathrm{it}}\right)+\beta_{\mathrm{KY}}\left(\ln \mathrm{K}_{\mathrm{it}}\right)\left(\ln \mathrm{Y}_{\mathrm{it}}\right)+ \\
& \beta_{\mathrm{LR}}\left(\ln \mathrm{L}_{\mathrm{it}}\right)\left(\ln \mathrm{R}_{\mathrm{it}}\right)+\beta_{\mathrm{LE}}\left(\ln \mathrm{L}_{\mathrm{it}}\right)\left(\ln \mathrm{E}_{\mathrm{it}}\right)+\beta_{\mathrm{LY}}\left(\ln \mathrm{L}_{\mathrm{it}}\right)\left(\ln Y_{\mathrm{it}}\right)+ \\
& \beta_{\mathrm{RE}}\left(\ln R_{\mathrm{it}}\right)\left(\ln E_{\mathrm{it}}\right)+\beta_{\mathrm{RY}}\left(\operatorname{lnR}_{\mathrm{it}}\right)\left(\ln \mathrm{Y}_{\mathrm{it}}\right)+\beta_{\mathrm{EY}}\left(\ln \mathrm{E}_{\mathrm{it}}\right)\left(\ln \mathrm{Y}_{\mathrm{it}}\right)+
\end{aligned}
$$

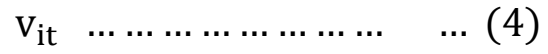

where $v_{i t}$ is a random variable accounting for statistical noise which is supposed to be normally distributed. Because of the properties of linearly homogenous energy in the Shephard energy distance function, equation (5) becomes

$$
\ln D_{E}\left(K_{i t}, L_{i t}, R_{i t}, E_{i t}, Y_{i t}\right)=\ln E_{i t}+\ln D_{E}\left(K_{i t}, L_{i t}, R_{i t}, 1, Y_{i t}\right)
$$

By substituting equation (4) to equation (5) and rearrange. It implies that

$$
\beta_{\mathrm{KE}}\left(\ln \mathrm{K}_{\mathrm{it}}\right)+\beta_{\mathrm{LE}}\left(\ln \mathrm{L}_{\mathrm{it}}\right)+\beta_{\mathrm{RE}}\left(\ln \mathrm{R}_{\mathrm{it}}\right)+\beta_{\mathrm{YE}}\left(\ln \mathrm{Y}_{\mathrm{it}}\right)=1-\beta_{\mathrm{E}}
$$

By substituting equation (6) to equation (4) and rearrange, it becomes that

$$
\begin{aligned}
& -\ln E_{i t}=\beta_{0}+\beta_{\mathrm{K}} \operatorname{LnK}_{\mathrm{it}}+\beta_{\mathrm{L}} \ln \mathrm{L}_{\mathrm{it}}+\beta_{\mathrm{R}} \ln \mathrm{R}_{\mathrm{it}}+\beta_{\mathrm{Y}} \ln \mathrm{Y}_{\mathrm{it}}+\beta_{\mathrm{E}} \ln 1+0.5 \beta_{\mathrm{KK}}\left(\ln \mathrm{K}_{\mathrm{it}}\right)^{2} \\
& +0.5 \beta_{\mathrm{LL}}\left(\ln \mathrm{L}_{\mathrm{it}}\right)^{2}+0.5 \beta_{\mathrm{RR}}\left(\operatorname{lnR}_{\mathrm{it}}\right)^{2}+0.5 \beta_{\mathrm{YY}}\left(\ln \mathrm{Y}_{\mathrm{it}}\right)^{2}+\beta_{\mathrm{KL}}\left(\ln \mathrm{K}_{\mathrm{it}}\right)\left(\ln \mathrm{L}_{\mathrm{it}}\right) \\
& +\beta_{\mathrm{KR}}\left(\ln \mathrm{K}_{\mathrm{it}}\right)\left(\ln \mathrm{R}_{\mathrm{it}}\right)+\beta_{\mathrm{KY}}\left(\ln \mathrm{K}_{\mathrm{it}}\right)\left(\ln \mathrm{Y}_{\mathrm{it}}\right)+\beta_{\mathrm{LR}}\left(\operatorname{lnL}_{\mathrm{it}}\right)\left(\ln \mathrm{R}_{\mathrm{it}}\right) \\
& +\beta_{\mathrm{LY}}\left(\ln \mathrm{L}_{\mathrm{it}}\right)\left(\ln Y_{\mathrm{it}}\right)+\beta_{\mathrm{RY}}\left(\operatorname{lnR}_{\mathrm{it}}\right)\left(\ln \mathrm{Y}_{\mathrm{it}}\right)+\mathrm{v}_{\mathrm{it}} \\
& -\ln \mathrm{D}_{\mathrm{E}}\left(\mathrm{K}_{\mathrm{it}}, \mathrm{L}_{\mathrm{it}}, R_{i t}, \mathrm{E}_{\mathrm{it}}, \mathrm{Y}_{\mathrm{it}}\right)
\end{aligned}
$$

Thus,

$$
\begin{aligned}
& \ln \left(1 / \mathrm{E}_{\mathrm{it}}\right)=\beta_{0}+\beta_{\mathrm{K}} \mathrm{LnK}_{\mathrm{it}}+\beta_{\mathrm{L}} \operatorname{lnL}_{\mathrm{it}}+\beta_{\mathrm{R}} \ln \mathrm{R}_{\mathrm{it}}+\beta_{\mathrm{Y}} \ln \mathrm{Y}_{\mathrm{it}}+0.5 \beta_{\mathrm{KK}}\left(\ln \mathrm{K}_{\mathrm{it}}\right)^{2}+0.5 \beta_{\mathrm{LL}}\left(\operatorname{lnL} \mathrm{L}_{\mathrm{it}}\right)^{2}+ \\
& 0.5 \beta_{\mathrm{RR}}\left(\ln \mathrm{R}_{\mathrm{it}}\right)^{2}+0.5 \beta_{Y Y}\left(\ln \mathrm{Y}_{\mathrm{it}}\right)^{2}+\beta_{\mathrm{KL}}\left(\ln \mathrm{K}_{\mathrm{it}}\right)\left(\ln \mathrm{L}_{\mathrm{it}}\right)+\beta_{\mathrm{KR}}\left(\operatorname{lnK}_{\mathrm{it}}\right)\left(\ln \mathrm{R}_{\mathrm{it}}\right)+ \\
& \beta_{\mathrm{KY}}\left(\ln K_{\mathrm{it}}\right)\left(\ln \mathrm{Y}_{\mathrm{it}}\right)+\beta_{\mathrm{LR}}\left(\ln \mathrm{L}_{\mathrm{it}}\right)\left(\ln \mathrm{R}_{\mathrm{it}}\right)+\beta_{\mathrm{LY}}\left(\ln \mathrm{L}_{\mathrm{it}}\right)\left(\ln \mathrm{Y}_{\mathrm{it}}\right)+\beta_{\mathrm{RY}}\left(\operatorname{lnR}_{\mathrm{it}}\right)\left(\ln \mathrm{Y}_{\mathrm{it}}\right)+ \\
& v_{i t}-u_{i t}
\end{aligned}
$$

where $u_{i t}=\ln D_{E}\left(K_{i t}, L_{i t}, R_{i t}, E_{i t}, Y_{i t}\right)$ is a non-negative variable accounting for energy efficiency. As a result, the SFA model presented as equation (8) can be derived from the Shephard energy distance function. The ML technique can be used to evaluate the parameters in equation (8). After the evaluation of equation (8), the energy inefficiency component $\widehat{u_{l t}}$ can be attained and the corresponding energy efficiency can be measured with $\mathrm{EE}=\exp (-$ $\left.\widehat{u_{l t}}\right)$. It is assumed that $u_{i t}$ is assumed to be a truncation of the normal distribution. The determinants of inefficiency can be simultaneously examined by Battese and Coelli (1995). 
$\mathrm{u}_{\mathrm{it}}=\delta_{0}+\sum_{\mathrm{j}=1}^{\mathrm{j}} \delta_{\mathrm{j}} \mathrm{H}_{\mathrm{jit}}+\varepsilon_{i t}$

where $H_{j i t}$ represents the environmental variables and each $\delta$ is the parameters to be estimated.

To apply the stochastic metafrontier model, this study follows the two-step SFA estimation of metafrontier analysis proposed by Huang, Huang \& Liu (2014). Assume that there are j-group in which $N_{j}$ mills that produce only one output with various inputs. Then the first step frontier stochastic input distance function for the group is:

$$
\begin{aligned}
& \ln \left(1 / E_{j i t}\right)=\beta_{0}+\beta_{K} \ln K_{j i t}+\beta_{L} \ln L_{j i t}+\beta_{R} \ln R_{j i t}+\beta_{Y} \ln Y_{j i t}+0.5 \beta_{K K}\left(\ln K_{j i t}\right)^{2} \\
& +0.5 \beta_{\mathrm{LL}}\left(\operatorname{lnL} \mathrm{j}_{\mathrm{jit}}\right)^{2}+0.5 \beta_{\mathrm{RR}}\left(\operatorname{lnR}_{\mathrm{jit}}\right)^{2}+0.5 \beta_{\mathrm{YY}}\left(\ln \mathrm{Y}_{\mathrm{jit}}\right)^{2}+\beta_{\mathrm{KL}}\left(\operatorname{lnK}_{\mathrm{jit}}\right)\left(\ln \mathrm{L}_{\mathrm{jit}}\right) \\
& +\beta_{\mathrm{KR}}\left(\ln K_{\mathrm{jit}}\right)\left(\ln \mathrm{R}_{\mathrm{jit}}\right)+\beta_{\mathrm{KY}}\left(\ln \mathrm{K}_{\mathrm{jit}}\right)\left(\ln Y_{\mathrm{jit}}\right)+\beta_{\mathrm{LR}}\left(\ln \mathrm{L}_{\mathrm{jit}}\right)\left(\ln \mathrm{R}_{\mathrm{jit}}\right) \\
& +\beta_{\mathrm{LY}}\left(\operatorname{lnL}_{\mathrm{jit}}\right)\left(\ln \mathrm{Y}_{\mathrm{jit}}\right)+\beta_{\mathrm{RY}}\left(\operatorname{lnR}_{\mathrm{jit}}\right)\left(\ln \mathrm{Y}_{\mathrm{jit}}\right)+\mathrm{v}_{\mathrm{jit}}-\mathrm{u}_{\mathrm{jit}}
\end{aligned}
$$

Before estimation of the second stage SFA regression, firstly, the optimal energy input is calculated by contracting the actual energy input; $E_{i t}^{*}=E_{i t} \times E_{j i t}$, in here $E_{i t}^{*}$ is optimal energy input, $E_{i t}$ is actual energy input and $E_{j i t}$ is the energy efficiency of mill $i$ at time $t$ from $\mathrm{j}$ group. The second stage SFA regression can be expressed as follow:

$$
\begin{aligned}
& \ln \left(1 / \mathrm{E}_{\mathrm{it}}^{*}\right)=\beta_{0}+\beta_{\mathrm{K}} \ln \mathrm{K}_{\mathrm{it}}+\beta_{\mathrm{L}} \ln \mathrm{L}_{\mathrm{it}}+\beta_{\mathrm{R}} \ln \mathrm{R}_{\mathrm{it}}+\beta_{\mathrm{Y}} \ln \mathrm{Y}_{\mathrm{it}}+0.5 \beta_{\mathrm{KK}}\left(\ln \mathrm{K}_{\mathrm{it}}\right)^{2} \\
& +0.5 \beta_{\mathrm{LL}}\left(\ln \mathrm{L}_{\mathrm{it}}\right)^{2}+0.5 \beta_{\mathrm{RR}}\left(\ln \mathrm{R}_{\mathrm{it}}\right)^{2}+0.5 \beta_{\mathrm{YY}}\left(\ln \mathrm{Y}_{\mathrm{it}}\right)^{2} \beta_{\mathrm{KL}}\left(\ln \mathrm{K}_{\mathrm{it}}\right)\left(\operatorname{lnL}_{\mathrm{it}}\right) \\
& +\beta_{\mathrm{KR}}\left(\operatorname{lnK}_{\mathrm{it}}\right)\left(\operatorname{lnR}_{\mathrm{it}}\right)+\beta_{\mathrm{KY}}\left(\ln _{\mathrm{it}}\right)\left(\ln _{\mathrm{it}}\right)+\beta_{\mathrm{LR}}\left(\operatorname{lnL}_{\mathrm{it}}\right)\left(\operatorname{lnR}_{\mathrm{it}}\right) \\
& +\beta_{\mathrm{LY}}\left(\ln \mathrm{L}_{\mathrm{it}}\right)\left(\ln \mathrm{Y}_{\mathrm{it}}\right)+\beta_{\mathrm{RY}}\left(\ln \mathrm{R}_{\mathrm{it}}\right)\left(\ln \mathrm{Y}_{\mathrm{it}}\right)+\mathrm{v}_{\mathrm{it}}^{*}-\mathrm{u}_{\mathrm{it}}^{*}
\end{aligned}
$$

From equation (11), the TGR of any mill $i$ at time $t$ can be interpreted as $u_{i t}^{*}=$ technology gap ratio $\left(\mathrm{TGR}_{\mathrm{it}}\right)$. According to the new two-stage of Huang et al. (2014), the following equation can be used to calculate meta frontier energy efficiency.

$\mathrm{MFEE}_{i \mathrm{t}}=\mathrm{EE}_{\mathrm{jit}} \times \mathrm{TGR}_{\mathrm{it}}$

where, $\mathrm{MFEE}_{\mathrm{it}}$ is the meta-frontier EE value for mill $\mathrm{i}$ at time $\mathrm{t} ; \mathrm{EE}_{\mathrm{jit}}$ is the group EE value for mill $i$ at time $t$; $\mathrm{TGR}_{i t}$ is the technology gap ratio for mill $i$ at time $t$. The values of MFEE, $\mathrm{EE}$, and TGR are between zero and one.

Several environmental variables $\left(H_{j i t}\right)$ are also considered to analyze the group energy efficiency and to analyze the technology gap ratio. These variables are the age of the mills (age), size of the mills (size), labor productivity (Labpro), percentage of capital owned by the government (Capgov), percentage of capital owned by private (Cappri), and percentage of capital owned by foreign (Capfor). These can be written in specific forms as follows;

$$
\begin{aligned}
& \mathrm{EE}_{\mathrm{jit}}=\delta_{0}+\delta_{1} \mathrm{Age}_{\mathrm{jit}}+\delta_{2} \operatorname{Size}_{\mathrm{jit}}+\delta_{3} \text { Labpro }_{\mathrm{jit}}+\delta_{4} \operatorname{Capgov}_{\mathrm{jit}}+\delta_{5} \text { Cappri }_{\mathrm{jit}}+ \\
& \delta_{6} \text { Capfor }_{\mathrm{jit}}+\varepsilon_{\mathrm{jit}}
\end{aligned}
$$




$$
\begin{aligned}
& \mathrm{TGR}_{\mathrm{it}}=\delta_{0}+\delta_{1} \text { Age }_{\mathrm{it}}+\delta_{2} \text { Size }_{\mathrm{it}}+\delta_{3} \text { Labpro }_{\mathrm{it}}+\delta_{4} \text { Capgov }_{\mathrm{it}}+\delta_{5} \text { Cappri }_{\mathrm{it}}+
\end{aligned}
$$

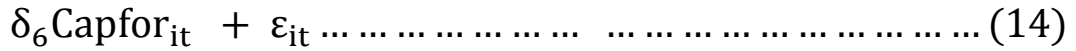

In this study, the sample panel data in 2010-2014 include the sugar mills of Indonesia in 42 regencies in which sugar mills are located. The period of 2010-2014 is selected as a study period based on the newly updated ISIC (International Standard of Industrial Classification) code and Indonesian Government Road Map for a short-term period in the sugar industry (2010-2014). To apply the metafrontier analysis, the mills in 42 regencies are divided into two groups according to their location. The mills in East Java are classified as group 1 and the mills in other provinces are classified as group 2 because $48.5 \%$ of the sugar mills are located in East Java and the number of sugar mills in each other province is too small. Thus, the mills in other provinces are combined in one group. There are nine provinces in another group namely, West Java, Central Java, Daista Yogyakarta, Banten, North Sumatera, South Sumatera, Lampung, South Sulawesi, and Gorontalo.

Data are taken from the secondary data of the BPS (Indonesia Central Board of Statistics). All the variables expressed in monetary terms are converted by using a wholesale price index (WPI) published by BPS at a constant price of 2010. The output variable, gross total output, Y, is characterized as the total amount of the output of a mill in a specific year. The capital stock is calculated by the replacement value of fixed assets. The value of fixed assets contains land, buildings, machinery equipment, vehicles, and other capital goods. The number of employees is used as a measurement of the labor variable. The raw material is the sum of costs of raw materials including domestic and imports. Energy included all kinds of energy such as gasoline, diesel fuel, kerosene, coal, coal briquettes, gas from PGN, gas from others, LPG, lubricants, and other fuels (coke, Fuel oil, Bunker C and MFO). All the different units of energy measurement are converted into the standard unit of barrel oil equivalent (BOE). The environmental variables included in the models are the age of the mill, size of the mill, labor productivity, and capital ownership. The age of the mill is the length of the mill's operation time and this is measured by year. Because of data availability, the age of the mill is measured from 1975 to 2014 in this study. The size of the mill is calculated as a logarithmic value of the value-added of the mill. Labor productivity is calculated in terms of labor cost per worker. Capital ownership is measured by the percentage of capital owned by the central government, domestic private, and foreign. Summary statistics of variables are presented in table (1).

In group 1, the average energy consumption is 6,082.33 with a standard deviation value of 15,634.34. The minimum and maximum values of energy consumption are 15.50 and $167,320.3$ respectively. The average value of capital is 21.58 billion rupiahs with a standard deviation of 50.78. The maximum value of capital in this group is 382.95 billion rupiahs. The minimum capital value is 0.06 billion rupiahs. This minimum value indicates that several mills have a value that is very far from the mill's average value of capital. For labor variables in this group, the minimum number of workers is 20 people, while the maximum number of workers in this industry is 2196 people. The minimum value of labor ( 20 people) indicates that this industry consists of only two types of mills. A mill is said to be a medium enterprise if the number of laborers in the mills is from 20 people up to 99 people. A mill is said to be a large enterprise if the number of laborers in the mills is more than 99 people. The average raw materials' value is 182.58 billion rupiahs with a standard deviation is $15,634.34$ billion rupiahs and the cost of raw material reaches a maximum of 1,887.36 billion rupiahs. 
In group 2, the average value of energy consumption is 32399.44 with a standard deviation of 63480.04. The smallest and largest values are 18.07 and 405181 respectively. The average value of capital is 43.79 billion rupiahs with a standard deviation of 161.10. The maximum value of capital in this group is 1811.74 billion rupiahs. The minimum capital value is 0.021 billion rupiahs. For labor variables in this group, the minimum number of workers is 23 people, while the maximum 466.15 billion rupiahs with standard deviation is $1,467.82$ billion rupiahs and the cost of raw material reaches the maximum of $14,805.18$ billion rupiahs. According to statistics, the average output of group 2 is higher than about 2.3 times the average output of group 1. But the average energy consumption of group 2 is higher than about five times group 1 . It can be seen that group 1 can manage energy use in the production process than group 2 in the study period.

The average year of the mills' operation period in group 1 is about 36 years with a standard deviation of 5.60. The mills' operation period ranges from 4 years to 39 years. The size of the mills has a mean value of 0.005 billion rupiahs. The smallest value is 0.0039 billion rupiahs and the largest value is 0.0068 . The standard deviation of the size of the mill is 0.0063 billion rupiahs. The labor quality of mills has an average value of 20.48 billion rupiahs with a standard deviation of 22.39 billion rupiahs and the smallest value of 0.0280 billion rupiahs and the largest value of 140.40 billion rupiahs. This showed that the difference in the productivity of labor is large in this group. The average value of the percentage of capital owned by the government, private, and foreigners are $51.63,34.88$, and 13.49 respectively.

The average year of the mills' operation period in group 2 is about 25 years with a standard deviation of 11.70. The mills' operation period ranges from 2 years to 39 years. The size of the mills has an average value of 5.14 billion rupiahs with the smallest value of 0.002 billion rupiahs and the largest value of 0.006 . The standard deviation of the size of the mill is 0.006 billion rupiahs. The labor quality of mills has an average value of 26.31 billion rupiahs with a standard deviation of 36.58 billion rupiahs and the smallest value of 0.11 billion rupiahs and the largest value of 346.63 billion rupiahs. The average value of the percentage of capital owned by the government, private, and foreigners are 44.60, 46.27, and 25.71 respectively. According to the statistics, the average age in group 1 is higher than group 2 because most of the older mills are located in group 1. The average size of the two groups is not much different. The quality of labor is higher than in group 2, which means that group 2 has more skilled labor than group 2. In terms of capital ownership, capital owned by the government is highest in group 1 because most of the mills owned by the government are located in group 1 . In group 2, capital owned by private is highest, which means that most of the mills in group 2 are private ownership.

Table 1: Summary statistics of sugar mills

\begin{tabular}{|c|c|c|c|c|c|c|c|c|c|}
\hline \multirow{2}{*}{ Variables } & \multirow{2}{*}{ Units } & \multicolumn{4}{|c|}{ Group 1 (East Java) } & \multicolumn{4}{|c|}{ Group 2 (Other provinces) } \\
\hline & & Mean & Std.Dev & Min & Max & Mean & Std.Dev & Min & $\operatorname{Max}$ \\
\hline $\begin{array}{l}\text { Energy } \\
\text { (E) }\end{array}$ & $\mathrm{BOE}$ & 6082.33 & 15634.34 & 15.50 & 167320.3 & 32399.44 & 63480.04 & 18.07 & 405181 \\
\hline Capital (K) & $\begin{array}{l}\text { Billion } \\
\text { Rupiah }\end{array}$ & 21.58 & 50.78 & 0.06 & 382.59 & 43.79 & 161.10 & 0.021 & 1811.74 \\
\hline Labor (L) & Number & 851.77 & 427.35 & 20.00 & 2196.00 & 1041.81 & 1.14 & 23 & 7862 \\
\hline $\begin{array}{l}\text { Raw } \\
\text { Materials } \\
(\mathrm{R})\end{array}$ & $\begin{array}{l}\text { Billion } \\
\text { Rupiah }\end{array}$ & 182.58 & 257.55 & 2.29 & 1887.36 & 466.15 & 1467.82 & 0.75 & 14805.18 \\
\hline Output (Y) & $\begin{array}{l}\text { Billion } \\
\text { Rupiah }\end{array}$ & 372.58 & 459.92 & 12.54 & 3032.04 & 841.97 & 2197.52 & 1.41 & 20345.13 \\
\hline Age & Year & 35.81 & 5.60 & 4 & 39 & 25.46 & 11.70 & 2 & 39 \\
\hline
\end{tabular}


ENERGY EFFICIENCY OF INDONESIA'S SUGAR INDUSTRY BASED ON ECONOMIC FRAMEWORK: STOCHASTIC METAFRONTIER ANALYSIS

Thinzar Win, Dyah Wulan Sari and Tri Haryanto

\begin{tabular}{llllllllll}
\hline Size & $\begin{array}{l}\text { Billion } \\
\text { Rupiah }\end{array}$ & 0.005 & 0.0005 & 0.004 & 0.0063 & 5.14 & 0.006 & 0.002 & 0.006 \\
\hline Labpro & $\begin{array}{l}\text { Billion } \\
\text { Rupiah }\end{array}$ & 20.48 & 22.39 & 0.0280 & 140.40 & 26.31 & 36.58 & 0.11 & 346.63 \\
\hline Capgov & $\%$ & 51.63 & 49.89 & 0 & 100 & 29.37 & 44.60 & 0 & 100 \\
\hline Cappri & $\%$ & 34.88 & 46.98 & 0 & 100 & 62 & 46.27 & 0 & 100 \\
\hline Capfor & $\%$ & 13.49 & 32.99 & 0 & 100 & 8.62 & 25.71 & 0 & 100 \\
\hline $\begin{array}{l}\text { Number of } \\
\text { observations }\end{array}$ & & & 160 & & & 165 & & \\
\hline
\end{tabular}

Source: Indonesia Central Board of Statistics (BPS)

\section{RESULTS AND DISCUSSION}

The most important step in analyzing the frontier is choosing the best model for this industry. In this study, the Cobb-Douglas model and the Trans-log model are compared. The best model from these two models is selected by applying the log-likelihood ratio test by comparing the value of $\lambda$ with the value of the Chi-Square table. The likelihood Ratio (LR) test is $\lambda=\left[\frac{\mathrm{L}\left(\mathrm{H}_{1}\right)}{\mathrm{L}\left(\mathrm{H}_{0}\right)}\right]^{2}$ in which $\ln \left[\mathrm{L}\left(\mathrm{H}_{0}\right)\right]$ is the $\mathrm{LR}$ value of the Cobb Douglas model and $\ln$ $\left[\mathrm{L}\left(\mathrm{H}_{1}\right)\right]$ is the LR value of the trans-log model. The degree of freedom is the number of parameters in the restricted model. The null hypothesis is that the Cobb-Douglas form is a suitable production function frontier form against the translog specification. Based on the estimation result, the Cobb Douglas model is rejected. So, the trans-log model is the appropriate model for the sugar industry in Indonesia.

After testing for the best model, the next hypothesis is to test the necessity of the metafrontier technique in the sugar industry. This hypothesis is tested by the LR test, $\lambda=$ $\left[\frac{\mathrm{L}\left(\mathrm{H}_{1}\right)}{\mathrm{L}\left(\mathrm{H}_{2}\right)}\right]^{2}$, where $\ln \left[\mathrm{L}\left(\mathrm{H}_{0}\right)\right]$ is the value of the loglikelihood function for the stochastic frontier estimated by pooling the data for all mills in all groups and $\ln \left[\mathrm{L}\left(\mathrm{H}_{1}\right)\right]$ is the sum of the value of the loglikelihood functions for two group production frontiers. The degree of freedom is the distinction between the number of parameters obtained from the estimated value under $\mathrm{H}_{1}$ and $\mathrm{H}_{0}$. If all the mills share the same production frontier and the same technology, it does not need to apply metafrontier. Based on the result, the null hypothesis, the production frontier is homogeneous for two groups, is rejected and it can be concluded that the technology in these groups is different. Thus, the meta-frontier method is suitable to estimate the energy efficiency of the sugar industry in Indonesia. The hypothesis test is shown in table (2).

Table 2: Hypothesis test

\begin{tabular}{lccc}
\hline Null hypothesis; $\mathrm{H}_{0}$ & Test Statistics $(\lambda)$ & Critical Value $\left(\chi^{2}\right)$ & Decision \\
\hline $\begin{array}{l}\text { Cobb-Douglas form is a suitable production } \\
\text { function frontier }\end{array}$ & 20.62 & 13.28 & Reject \\
\hline $\begin{array}{l}\text { The production frontier is homogeneous for } \\
\text { two groups }\end{array}$ & 27.6 & 23.68 & Reject \\
\hline Source: Compilation by the author & & &
\end{tabular}

Table (3) reports the parameters estimates for efficiency and its determinants. Here, for environmental variables, a minus sign of the coefficient of variables describes that this variable is a factor increasing energy inefficiency and a plus sign of the coefficient of variables shows that this variable is a factor decreasing energy inefficiency (Honma \& $\mathrm{Hu}$, 2018; Hsiao, Hu, Hsiao, \& Chang, 2019). In this study, all the data are normalized around their means before estimating the data. 
Table (3) reports that capital is significant only in group 2 and labor is significant only in group 1. The raw material and output are significant in both groups. In terms of environmental factors that affect the energy efficiency (EE) of the sugar industry, the mill's age has an impact on energy efficiency at 5\% significance level in group 1only. The positive sign implies that the older the age of the mill, the more efficient energy consumption. This result is the opposite of Haider, Danish, and Sharma (2019) in which younger firms are more efficient in energy use. Based on the literature, the older mills have lower performance in energy efficiency. But, in Indonesia, Government collaborated with the state and private sectors to improve the sugar industry. In 2009 , the government invested $\$ 858.4$ million in state-owned plantations to expand land and to modernize the existing mills' facilities. For this reason, the mill's age is directly related to energy efficiency in East Java because most of the state-owned mills are located in this province.

The size of the mill positively affects energy efficiency in both groups showing that an increase in size induces energy efficiency. This is consistent with the previous study of Irawan, Hartono, and Achsani (2010), Mandal and Madheswaran (2011), and Haider et al. (2019). Among the ownership type, the percentage of capital owned by the government, private and foreign have a significant effect on both groups. However, negative signs imply that the ownership type has not helped the energy efficiency of mills in both groups. The value of $\gamma$ is

0.6350 and 0.9999 in group 1 and group 2 respectively which shows that the inefficiency variance is $63.5 \%$ and $99.99 \%$ of the total variance of error components in each group.

For Technology Gap Ratio, the output is significant at a 10\% significant level. The size of the mill has a positive effect on TGR, showing that the larger the size of the firm, the higher the TGR. This is in line with the assumption of various authors (Geroski, 2000; Hall \& Khan, 2002; Nelson \& Winter, 1982) in which large mills are much more likely to undertake a new technology for many reasons. All of the ownership types are significant at a $10 \%$ significant level but the negative signs of coefficients show that the ownership types cannot explain the TGR.

Table 3: Parameter estimates of efficiency and its determinants

\begin{tabular}{|c|c|c|c|c|c|c|}
\hline \multirow[b]{2}{*}{ Variable } & \multicolumn{2}{|c|}{ Group 1} & \multicolumn{2}{|c|}{ Group 2} & \multicolumn{2}{|c|}{ TGR } \\
\hline & Coefficient & t-ratio & Coefficient & t-ratio & Coefficient & t-ratio \\
\hline Constant $\left(\beta_{0}\right)$ & $0.8137 *$ & 2.9669 & $2.4519 *$ & 41.9004 & $2.2543^{*}$ & 6.6020 \\
\hline Capital $\left(\beta_{K}\right)$ & -0.0727 & -0.7221 & $0.1015 *$ & 5.2789 & -0.1066 & -0.9321 \\
\hline Labor $\left(\beta_{L}\right)$ & $0.5325 * *$ & 2.2202 & 0.2175 & 1.5670 & -0.0317 & -0.1414 \\
\hline Raw materials $\left(\beta_{R}\right)$ & $-0.6896 *$ & -2.8478 & $0.2740 *$ & 8.8213 & 0.1505 & 0.4983 \\
\hline Output $\left(\beta_{Y}\right)$ & $1.2898 *$ & 4.2118 & $0.4463 *$ & 13.6967 & $0.8205 * * *$ & 1.8788 \\
\hline Capital *Capital $\left(\beta_{K K}\right)$ & 0.1378 & 1.0644 & -0.0991 & -1.5471 & -0.0731 & -0.5213 \\
\hline Labor*Labor $\left(\beta_{L L}\right)$ & $0.6132 * *$ & 2.4749 & $-0.3314 * *$ & -2.4098 & 0.0712 & 0.3301 \\
\hline $\begin{array}{l}\text { Raw materials * Raw materials } \\
\left(\beta_{R R}\right)\end{array}$ & $-1.5171^{*}$ & -3.0297 & -0.0668 & -1.6219 & -0.1365 & -0.2306 \\
\hline Output $*$ Output $\left(\beta_{Y Y}\right)$ & $-1.3178 * * *$ & -1.7043 & $0.1539 * *$ & 2.1429 & 0.8754 & 1.1448 \\
\hline Capital * Labor $\left(\beta_{K L}\right)$ & -0.1787 & -1.0084 & $-0.2108 *$ & -3.7504 & $-0.3414 * *$ & -2.0726 \\
\hline Capital $*$ Raw materials $\left(\beta_{K R}\right)$ & -0.0376 & -0.2814 & -0.0049 & -0.2370 & 0.1765 & 0.9787 \\
\hline Capital $*$ Output $\left(\beta_{K Y}\right)$ & 0.1569 & 0.6946 & 0.0607 & 1.2789 & -0.0974 & -0.4251 \\
\hline Labor*Raw materials $\left(\beta_{L R}\right)$ & -0.1527 & -0.3823 & -0.0425 & -0.9604 & 0.2462 & -0.6964 \\
\hline Labor*Output $\left(\beta_{L R}\right)$ & 0.4953 & 0.8727 & $0.5537 *$ & 10.1000 & 0.7071 & 1.5714 \\
\hline Raw materials $*$ output $\left(\beta_{R Y}\right)$ & $1.3201 *$ & 2.6593 & -0.0140 & -0.4648 & -0.1654 & -0.2724 \\
\hline Constant $\left(\delta_{0}\right)$ & -0.0073 & -0.0073 & -0.0020 & -0.0020 & -0.0814 & -0.0184 \\
\hline Age $\left(\delta_{1}\right)$ & $0.1631 * *$ & 2.3989 & 0.0214 & 0.6311 & -0.0063 & -0.0797 \\
\hline Size $\left(\delta_{2}\right)$ & $3.0975 * *$ & 2.4464 & $1.5147 *$ & 3.8070 & $9.7905 * *$ & 1.9610 \\
\hline Labpro $\left(\delta_{3}\right)$ & $0.93 \mathrm{E}-05$ & 0.9723 & $-1.190 \mathrm{E}-05$ & -1.6065 & $0.19 \mathrm{E}-04$ & 1.1019 \\
\hline$\%$ of Capgov $\left(\delta_{4}\right)$ & $-0.2229 *$ & -2.6315 & $-0.0620 * *$ & -2.1579 & $-0.5806^{* * *}$ & -1.7174 \\
\hline
\end{tabular}


ENERGY EFFICIENCY OF INDONESIA'S SUGAR INDUSTRY BASED ON ECONOMIC FRAMEWORK: STOCHASTIC METAFRONTIER ANALYSIS

Thinzar Win, Dyah Wulan Sari and Tri Haryanto

\begin{tabular}{|c|c|c|c|c|c|c|}
\hline$\%$ of Cappri $\left(\delta_{5}\right)$ & $-0.2234 *$ & -2.5975 & $-0.0698 * *$ & -2.4460 & $-0.5822 * * *$ & 1.7195 \\
\hline$\%$ of capfor $\left(\delta_{6}\right)$ & $-0.2862 * *$ & -2.3976 & $-0.0679 * *$ & -2.2612 & $-0.6746 * * *$ & -1.7294 \\
\hline Sigma-squared $\left(\sigma^{2}\right)$ & $2.6348^{*}$ & 3.4926 & $5.2195 *$ & 8.4515 & $33.3331 * * *$ & 1.6458 \\
\hline $\operatorname{Gamma}(\gamma)$ & $0.6350 *$ & 4.7006 & 99.9999* & 5450669.9 & $0.9532 *$ & 35.7018 \\
\hline Log Likelihood & \multicolumn{2}{|c|}{-251.84} & \multicolumn{2}{|c|}{-289.58} & \multicolumn{2}{|c|}{-739.15} \\
\hline
\end{tabular}

Table (4) and table (5) shows the average value of EE within groups, technology gap ratio (TGR), and metafrontier EE (MFEE) of group 1 and group 2 during the period of 20102014. In the table (4), the results revealed that, in group 1, the mean energy efficiency of mills in Situbondo is highest and the score is 0.6709 , showing that mills in Situbondo could reduce the use of energy up to $67.09 \%$ of the real energy input given the same level of inputs, output, and technology in group 1. Most of the mills in other regencies have good average EE scores and the values are above 0.5. It can be also concluded that mills in each regency have well performance management in energy consumption in the production process. The average TGR scores of mills in group 1, the mills in Pasuruan, Situbondo, Megetan, Bondowoso, and Jember have the highest value of average TGR which values are $0.4633,0.3906,0.3819$, 0.3725 , and 0.3811 respectively. The other regencies have a very low level of average TGR. It can be concluded that the mills in Pasuruan, Situbondo, Megetan, Bondowoso, and Jember produce their product with better technology than mills in other regencies. Other regencies are very far away from the best technology available in this industry. For the average MFEE in group 1, the average MFEE level of mills in all regencies below the average level. Even though some mill has a high level of group average EE, their average MFEE is very low. For example, Situbondo, Pasuruan, and Magetan, the top three regencies concerning average group EE, are not efficient in their TGR value and MFEE values. Mills in all regencies whose group mean $\mathrm{EE}$ is greater than their mean TGR values. It can be concluded that the inefficiency of MFEE is concerned with the technology used in this group rather than their operational management within their mills. The mean value of group EE, TGR, and MFEE in table (4) shows that the mean value of group EE of mills in East Java is 0.5484, showing that East Java could decrease in energy use up to $54.84 \%$ of real energy input by a given level of same inputs, output, and production technology in East Java. The mean TGR of East Java, 0.3016, shows that East Java could reduce energy inputs by another 69.84\% (1-0.3016) keeping the same inputs and output and best available technology. In total, East Java could decrease energy consumption by $79.98 \%$ (1-0.2002) using meta-technology.

Table 4: Average value of EE, TGR, and MFEE

\begin{tabular}{lccc}
\hline Group 1 (East Java) & EE & TGR & MFEE \\
\hline Bondowoso & 0.6043 & 0.3811 & 0.2303 \\
\hline Jember & 0.4638 & 0.3629 & 0.1683 \\
\hline Jombang & 0.6300 & 0.3725 & 0.2347 \\
\hline Kediri & 0.4385 & 0.1920 & 0.0842 \\
\hline Lumajang & 0.6193 & 0.3004 & 0.1860 \\
\hline Madiun & 0.6118 & 0.3385 & 0.2071 \\
\hline Magetan & 0.6490 & 0.3819 & 0.2478 \\
\hline Malang & 0.4276 & 0.2728 & 0.1166 \\
\hline Mojokerto & 0.5154 & 0.2426 & 0.1250 \\
\hline Nganjuk & 0.4042 & 0.2351 & 0.0950 \\
\hline Ngawi & 0.5904 & 0.2814 & 0.1661 \\
\hline Pasuruan & 0.6677 & 0.4633 & 0.3093 \\
\hline
\end{tabular}




\begin{tabular}{llll}
\hline Probolinggo & 0.6069 & 0.3239 & 0.1965 \\
\hline Sidoarjo & 0.3899 & 0.1744 & 0.0680 \\
\hline Situbondo & 0.6709 & 0.3906 & 0.2621 \\
\hline Tunungagung & 0.4661 & 0.2244 & 0.1046 \\
\hline Mean & 0.5484 & 0.3016 & 0.2002 \\
\hline
\end{tabular}

Source: Compilation by the author

In the table (5), in group 2, the mills in Kendal, Central Java province, is the highest mean energy efficiency scores and the value is 0.7767 , implying that mills in this province can reduce $77.67 \%$ of energy use in their production process by using the same inputs, output, and same technology. Mills in other regencies could not well-perform in energy use. In group 2, Kendal (Central Java province), Barru (South Sulawesi province), and Bantul (Daista Yogyakarta) have a greater value of average TGR compared with mills in other regencies. Mills in Serang, Bantan province, is the lowest TGR and the value is 0.0003. According to this figure, the technology gap between mills in each regency is very large. In group 2, the group means EE of most of the regencies is low and their MFEE value is also low. Mills in all regencies except Serang, Tegal, Cirebon, Pemalang, and Pati whowho'san TGR is greater than the group means EE. It can be said that the inefficiency of the MFEE in this group comes from operational inefficiency rather than the technology gap used in this group. In the table (5), the results of other provinces showed that the mean group EE is 0.2334 , showing that other provinces could decrease energy inputs by $23.34 \%$ of actual energy input by keeping the same other inputs and outputs with the available technology in these provinces. The value of mean TGR (0.2506) means that other provinces could reduce the energy input by another 74.94\% (1-0.2506) keeping the same inputs and output with the best available technology. Overall, other provinces could reduce energy consumption by $88.66 \%$ (1-0.1134) by applying meta-technology. According to this data, group EE, TGR, and MFEE show that East Java can perform better than other provinces.

Table 5: Average value of EE, TGR, and MFEE of group 2

\begin{tabular}{lccc}
\hline Group 2 (other povinces) & EE & TGR & MFEE \\
\hline Serang & 0.0021 & 0.0001 & 0.0000003 \\
\hline Cilegon & 0.2571 & 0.2880 & 0.0740 \\
\hline Bantul & 0.4109 & 0.6703 & 0.2755 \\
\hline Boalemo & 0.3271 & 0.5916 & 0.1935 \\
\hline Cirebon & 0.1176 & 0.0799 & 0.0094 \\
\hline Majalengka & 0.1983 & 0.4222 & 0.0837 \\
\hline Subang & 0.1596 & 0.3772 & 0.0602 \\
\hline Tegal & 0.0350 & 0.0201 & 0.0007 \\
\hline Kudus & 0.0662 & 0.0568 & 0.0038 \\
\hline Brebes & 0.1247 & 0.2377 & 0.0296 \\
\hline Pekalongan & 0.4378 & 0.5177 & 0.2267 \\
\hline Pemalang & 0.1590 & 0.1349 & 0.0214 \\
\hline Klaten & 0.2383 & 0.3915 & 0.0933 \\
\hline Sragen & 0.0585 & 0.0596 & 0.0035 \\
\hline Karanganyar & 0.2726 & 0.3185 & 0.0868 \\
\hline Pati & 0.3721 & 0.3572 & 0.1329 \\
\hline Kendal & 0.7767 & 0.8017 & 0.6227 \\
\hline Tulang Bawang & 0.0928 & 0.2342 & 0.0217 \\
\hline Tanggamus & 0.0516 & 0.0570 & 0.0029 \\
\hline Waykanan & 0.4045 & 0.6400 & 0.2589 \\
\hline
\end{tabular}


ENERGY EFFICIENCY OF INDONESIA'S SUGAR INDUSTRY BASED ON ECONOMIC FRAMEWORK: STOCHASTIC METAFRONTIER ANALYSIS

Thinzar Win, Dyah Wulan Sari and Tri Haryanto

\begin{tabular}{llll}
\hline East Lampung & 0.1098 & 0.4429 & 0.0486 \\
\hline Barru & 0.4814 & 0.6643 & 0.3198 \\
\hline Takalar & 0.2235 & 0.4706 & 0.1052 \\
\hline Ogan Ilir & 0.1683 & 0.3461 & 0.0582 \\
\hline Toba samosir & 0.0790 & 0.0586 & 0.0046 \\
\hline Mandailing Natal & 0.0692 & 0.1315 & 0.0091 \\
\hline Mean & 0.2334 & 0.2506 & 0.1134 \\
\hline
\end{tabular}

Source: Compilation by the author

\section{CONCLUSIONS AND SUGGESTION}

In this study, the energy efficiency of the sugar industry from 2010 to 2014 are examined under the meta stochastic frontier approach. The energy efficiency of Indonesia's sugar industry is still low in both the meta-frontier or group frontier. This means that there is a large room to save energy consumption in this industry. During the study period, the score of average TGR in East Java is slightly larger than the value of average TGR in other provinces. But the value of average TGR is lower than the value of group average EE in East Java and higher than in other provinces. According to this, East Java needs to focus more on their production environment and other provinces need to focus more on their operational environment. The score of energy efficiency in the group frontier is greater than the meta frontier, which indicates that there is a considerable technological gap between the group frontier and meta-frontier. Another reason for lowering MFEE is a low level of group EE. In conclusion, both provinces need to focus both on operational and production environments closer to the meta frontier. For the environmental factors affecting energy efficiency, the age of the mills has an effect on energy efficiency in East Java. The size of the mills has an effect on energy efficiency in both groups and it also affects the TGR.

The outcome of this study also provides the following policy suggestions. To achieve energy saving in the sugar industry, the government should create the opportunity for advanced technology, should invite the technical know-how from abroad, and also provide technological training. In terms of managerial aspects, the owners of the mills need to eliminate the old production apparatus which consumes a huge amount of energy in the production process. Large technological gap levels will be a barrier in the long run progress of efficiency of total energy use in the sugar industry. To close this gap, policymakers should consider the appropriate policy for each province. The owner of mills, they should consider their managerial environment to increase their efficiency in energy and need to replace old technology with the new one to upgrade the technology. Finally, the industry-specific environmental factors that may have a possible impact on meta-frontier energy efficiency (MFEE) will be considered for further study. This can provide more specific information for effective policies. 


\section{REFERENCES}

Azhari, R. (2018). Analysis of efficiency of sugar industry in Indonesia (2000-2014). [Unpublished thesis]. Universitas Sriwijaya.

Battese, G. E., \& Coelli, T. J. (1995). A Model for Technical Inefficiency Effects in a Stochastic Frontier Production Function for Panel Data. Empirical Economics, 20, 325332.

Geroski, P. A. (2000). Models of technology diffusion. Research Policy, 29(4-5), 603-625.

Haider, S., Danish, M. S., \& Sharma, R. (2019). Assessing energy efficiency of Indian paper industry and influencing factors: A slack-based firm-level analysis. Energy Economics, $81,454-464$.

Hall, B. H., \& Khan, B. (2002). Adoption of new Technology. New Economy Handbook, 38. University of California at Berkeley.

Hayami, Y., \& Ruttan, V. W. (1970). Agricultural Productivity Differences among Countries. American Economic Review, 60(5), 895-911.

Honma, S., \& Hu, J. L. (2018). A meta-stochastic frontier analysis for energy efficiency of regions in Japan. Journal of Economic Structures, 7(1), 21. Springer Berlin Heidelberg. Retrieved from https://doi.org/10.1186/s40008-018-0119-x

Hsiao, W. L., Hu, J. L., Hsiao, C., \& Chang, M. C. (2019). Energy efficiency of the baltic sea countries: An application of stochastic frontier analysis. Energies, 12(1), 104.

Huang, C. J., Huang, T. H., \& Liu, N. H. (2014). A new approach to estimating the metafrontier production function based on a stochastic frontier framework. Journal of Productivity Analysis, 42(3), 241-254.

International Center for Applied Finance and Economics. (2018). Market Study on Food Sector in Indonesia. Jakarta

Irawan, T., Hartono, D., \& Achsani, N. A. (2010). An Analysis Of Energy Intensity In Indonesian Manufacturing ( No. 201007). Working Paper in Economics and Development Studies, No. 21007.

ISO. (2019). International Sugar Organization, Sugar Year Book. London.

Mandal, S. K., \& Madheswaran, S. (2011). Energy use efficiency of Indian cement companies: A data envelopment analysis. Energy Efficiency, 4(1), 57-73.

McDonald, G., \& Meylinah, S. (2019). Indonesia Sugar Annual Report 2019. Global Agricultural Information Network.

Ministry of Industry. (2012). Planning for Industrial Sector Energy Demand in the Context of Accelerated Industrialization, Indonesia. Jakarta. 
ENERGY EFFICIENCY OF INDONESIA'S SUGAR INDUSTRY BASED ON ECONOMIC FRAMEWORK: STOCHASTIC METAFRONTIER ANALYSIS

Thinzar Win, Dyah Wulan Sari and Tri Haryanto

Nelson, R., \& Winter, S. G. (1982). An Evolutionary Theory of Economic Change (First edit.). The Belknap Press of Harvard University Press.

Priambodo, A., \& Kumar, S. (2001). Energy use and carbon dioxide emission of Indonesian small and medium scale industries. Energy Conversion and Management, 42(11), 13351348.

Ramstetter, E. D., \& Narjoko, D. (2014). Ownership and Energy Efficiency in Indonesian Manufacturing. Bulletin of Indonesian Economic Studies, 50(2), 255-276.

Sugiharti, L., Purwono, R., Primanthi, M. R., \& Padilla, M. A. E. (2017). Indonesian productivity growth: Evidence from the manufacturing sector in Indonesia. Journal of Social Sciences and Humanities, 25(November), 29-44.

Susila, W. R., \& Sinaga, B. M. (2005). Analysis Policy of National Sugar Industry. Jurnal Agro Ekonomi, 23(1).

United Nations Industrial Development Organization. (2017). Sugar Mill Sector Pagottan Sugar Mill PTPN-XI East Java, Indonesia, Resource Efficient and Cleaner Production Program.

Vivadinar, Y., Purwanto, W. W., \& Saputra, A. H. (2012). What are the Key Drivers of Energy Intensity in Indonesia Manufacturing Sectors? International Congress on Informatics, Environment, Energy and Applications-IEEA 2012, 38.

Vivadinar, Y., Purwanto, W. W., \& Saputra, A. H. (2016). Tracing the energy footprints of Indonesian manufacturing industry. Energy Science and Engineering, 4(6), 394-405.

Zhou, P., Ang, B. W., \& Zhou, D. Q. (2012). Measuring economy-wide energy efficiency performance: A parametric frontier approach. Applied Energy, 90(1), 196-200. Elsevier Ltd. Retrieved from http://dx.doi.org/10.1016/j.apenergy.2011.02.025 